University of Pittsburgh School of Law

Scholarship@PITT LAW

\title{
The Future of Law Schools: COVID-19, Technology, and Social Justice
}

Christian Sundquist

University of Pittsburgh School of Law, sundquist@pitt.edu

Follow this and additional works at: https://scholarship.law.pitt.edu/fac_articles

Part of the Curriculum and Social Inquiry Commons, Education Law Commons, Law and Race Commons, Law and Society Commons, Legal Education Commons, Legal Profession Commons, Other Anthropology Commons, Science and Technology Law Commons, Science and Technology Studies Commons, Social and Cultural Anthropology Commons, and the Social Justice Commons

\section{Recommended Citation}

Christian Sundquist, The Future of Law Schools: COVID-19, Technology, and Social Justice, 53 Connecticut Law Review Online 1 (2020).

Available at: https://scholarship.law.pitt.edu/fac_articles/490

This Article is brought to you for free and open access by the Faculty Publications at Scholarship@PITT LAW. It has been accepted for inclusion in Articles by an authorized administrator of Scholarship@PITT LAW. For more information, please contact leers@pitt.edu, shephard@pitt.edu. 


\section{CONNECTICUT LAW REVIEW}

\begin{tabular}{lll}
\hline \hline VOLUME 53(1) & DECEMBER 2020 & ONLINE EDITION \\
\hline \hline
\end{tabular}

\section{Article}

\section{The Future of Law Schools: Covid-19, Technology, and Social Justice}

\section{CHRISTIAN SUNDQUIST}

The COVID-19 pandemic has laid bare not only the social and racial inequities in society, but also the pedagogical and access to justice inequities embedded in the traditional legal curriculum. The need to reenvision the future of legal education existed well before the current pandemic, spurred by the shifting nature of legal practice as well as demographic and technological change. This article examines the impact of the COVID-19 pandemic on legal education, and posits that the combined forces of the pandemic, social justice awareness and technological disruption will forever transform the future of both legal education and practice. 


\section{ARTICLE CONTENTS}

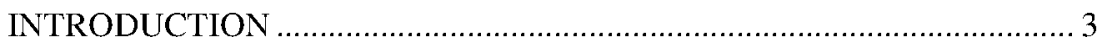

I. LAW SCHOOL RESPONSES TO THE COVID-19 PANDEMIC .............. 5

II. SOCIAL JUSTICE ACTIVISM AND LAW SCHOOLS ......................... 11

III. TECHNOLOGICAL DISRUPTION IN LEGAL EDUCATION AND

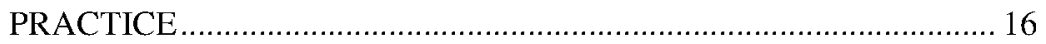

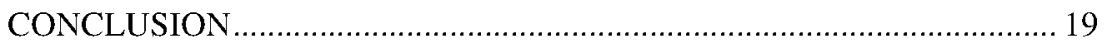

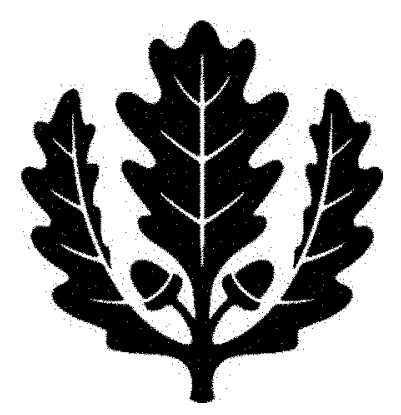




\section{The Future of Law Schools: Covid-19, Technology, and Social Justice}

CHRISTIAN SUNDQUIST*

\section{INTRODUCTION}

The COVID-19 pandemic has laid bare not only the social and racial inequities in society, ${ }^{1}$ but also the pedagogical and access to justice inequities embedded in the traditional legal curriculum. The need to reenvision the future of legal education existed well before the current pandemic, spurred by the shifting nature of legal practice as well as demographic and technological change. ${ }^{2}$ This article examines the impact of the COVID-19 pandemic on legal education, and posits that the combined forces of the pandemic, social justice awareness, and technological disruption will forever transform the future of both legal education and practice.

The COVID-19 pandemic is occurring during a moment of significant technological disruption in legal education. Advancements in online teaching, online courts, predictive analytics, and artificial intelligence technologies have already called into question the traditional conceptions of both law school and legal practice. ${ }^{3}$ Some are concerned that such technologies will undermine the quality of legal instruction while rendering many traditional legal jobs obsolete. ${ }^{4}$ Others are hopeful that technological change will lead to greater efficiencies in legal practice, create new technolegal jobs, and expand the public's access to justice. ${ }^{5}$

\footnotetext{
${ }^{*}$ Professor of Law and Director of Faculty Research and Scholarship, Albany Law School.

${ }^{1}$ See, e.g., Liam Petterson, Coronavirus Weekly: Racism, COVID-19, and the Inequality That Fuels These Parallel Pandemics, THE CONvERSATION (June 9, 2020, 1:26 AM), https://theconversation com/coronavirus-weekly-racism-covid-19-and-the-inequality-that-fuels-theseparallel-pandemics-140255 (discussing the race and class-based disparities of the COVID-19 pandemic).

${ }^{2}$ See, e.g., RICHARD SUSSKIND, TOMORROW'S LAWYERS: AN INTRODUCTION TO YOUR FUTURE passim (2d ed. 2017) (predicting fundamental and irreversible changes in the world of law); Jakki Petzold, LSSSE Demographic Characteristics Reflect the U.S. Law Student Population, LSSSE (Nov. 6 , 2018), https://lssse.indiana.edu/blog/lssse-demographic-characteristics-reflect-the-u-s-law-studentpopulation/ (examining demographic changes in law school enrollment).

${ }^{3}$ See SUSSKIND, supra note 2, at 3-15 (Susskind, perhaps the preeminent futurist on legal education, predicts that "disruptive legal technologies" will fundamentally alter both the legal market and legal education).

${ }^{4}$ See, e.g., id at $132-40$ (predicting that disruptive legal technologies will fundamentally alter the role of "conventional lawyers").

${ }^{5}$ See, e.g., Milan Markovic, Rise of the Robot Lawyers?, 61 ARIZ. L. REv. 325, 328 (2019) (exploring technology's impact on legal education); Raymond H. Brescia, When Interests Converge: An Access-to-Justice Mission for Law Schools, 24 GEO. J. POVERTY L. \& POL'Y 205, 207 (2017) (same).
} 
The pandemic-by unmasking the latent race, gender, and health disparities in our society - has also renewed public (and student) interest in social justice. The racial justice outcry following the killings of George Floyd, Ahmaud Arbery, and Breonna Taylor (and so many others) have caused law students and others to advocate for structural changes to legal education, including calls to re-envision the traditional law curriculum to incorporate a broader scope of required and elective courses on racial justice. $^{6}$

Legal education was forced to quickly respond to these structural forces when the COVID-19 pandemic suddenly appeared in the middle of the Spring 2020 semester. $^{7}$ Law schools abruptly shifted to remote-learning methodologies as an emergency response to the coronavirus, with varying degrees of success. ${ }^{8}$ Law schools are now implementing a variety of temporary pedagogical and safety responses to the COVID-19 pandemic in preparation for the 2020-2021 academic year. ${ }^{9}$ The collective forces of COVID-19, social justice awareness, and technological change, however, demand that law schools use this unique moment in time as an opportunity to completely re-envision legal education.

This article anticipates that online learning methodologies will continue to reshape legal pedagogy in light of the COVID-19 pandemic, technological innovation, and the financial pressures facing most law schools. This provides law schools, however, with an opportunity to cultivate the potential benefits of online pedagogy (such as preparing students for online practice

\footnotetext{
${ }^{6}$ See Brian Keyes, UNC School of Law Responds to Letter from Group of Black Students, DALI Y TAR HEEL (June 29, 2020, 9:56 PM), https://www.dailytarheel.com/article/2020/06/law-school-racialjustice (describing demands by law students to increase faculty diversity and provide required courses on Critical Race Theory); Ashleen O'Brien, Law Students Demand Racial Justice, DAILY (Jan. 10, 2020), http://www.dailyuw.com/opinion/article_ce8aed20-33ce-11ea-8199-97abff1e6f79.html (discussing requests from law students to re-envision the traditional curriculum to meaningfully address issues of race and bias); Karen Sloan, "This is the Civil Rights Movement of My Lifetime": Black Law Students Demand Action, LAw.COM (June 18, 2020) [hereinafter Sloan, "This is the Civil Rights Movement of My Lifetime"], https://www.law.com/2020/06/18/this-is-the-civil-rights-movement-of-my-lifetime-blacklaw-students-demand-action/ (summarizing the national law student movement to incorporate racial justice in law school programming, curriculum, and hiring); Florida's 12 Law Schools Form New Consortium for Racial Justice, STETSON UNIV.: STETSON L. NEWS (June 24, 2020), https://www.stetson.edu/law/news/index.php/2020/06/24/the-states-12-law-schools-propose-solidarityand-unified-approach-with-new-florida-law-schools-consortium-for-racial-justice (addressing efforts by Florida law schools to address racial justice issues); Areeba Jibril, McKayla Stookes, \& Mariah Young., Students Take to Twitter to Demand Racial Equality, A.B.A. FOR L. STUDENTS (July 1, 2020), https://abaforlawstudents.com/2020/07/01/students-take-to-twitter-to-demand-racial-equality/

(addressing the efforts of law school students to require racial justice programming and diversity initiatives)

${ }^{7}$ See Karen Sloan, Online or in Person? Law Schools Diverge in Fall Semester Plans, LAw.COM (July 1, 2020) [hereinafter Sloan, Online or in Person?], https://www.law.com/2020/07/01/online-or-inperson-law-schools-diverge-in-fall-semester-plans/ (examining how many law schools shifted to remotelearning at the beginning of the COVID-19 crisis).

${ }^{8}$ See id.

${ }^{9}$ See id.
} 
and virtual courts, decreasing costs, and responding to the needs of nontraditional students) while mitigating the negative aspects of remote learning (such as impaired discussion and analysis of legal issues, the use of flawed online teaching methodologies, the difficulty of creating community-building and experiential experiences, and student difficulty in creating positive learning environments at home).

Part I of this article examines the responses of law schools around the country to the COVID-19 pandemic, considering both the emergency remote-learning tools adopted by schools during the Spring 2020 semester as well as online teaching plans being adopted for the 2020-2021 academic year. Part II of this article explores recent calls by law students, faculty, and deans to incorporate racial and social justice issues in the law school curriculum and to increase the number of tenure-track and tenured BIPOC law faculty. This section will also address a novel ABA Proposal submitted in August 2020 to form a Task Force to study the adoption of mandatory law school courses on antiracism, bias, and cultural competency. Part III of this article examines the current and future impact of technology on legal education, paying particular attention to the disruptive role of artificial intelligence software. The article will conclude by offering predictions on the future impact of COVID-19, technological innovation, and social justice demands on legal education, and by providing recommendations for law school reform.

\section{LAW SCHOOL RESPONSES TO THE COVID-19 PANDEMIC}

The disruption to law schools caused by the COVID-19 pandemic has been massive. Faculty, administrators, and students were forced to abruptly transition from more traditional teaching methodologies (such as in-person instruction with generally limited online course opportunities) to remotelearning platforms (both synchronous and asynchronous) in the middle of the spring 2020 semester. ${ }^{10}$ The American Bar Association ("ABA"), the primary national accrediting entity for law schools, ${ }^{11}$ moved to expand the pre-existing restrictions on offering online courses this past spring. ${ }^{12}$ While students previously were only able to take up to one-third of their academic credits through online "distance education" courses under ABA Standard 306 , the newly proposed rule authorized the ABA's Section of Legal

${ }^{10}$ Cathy Li \& Farah Lalani, The COVID-19 Pandemic has Changed Education Forever. This is How, WORLD ECON. F. (Apr. 29, 2020), https://www.weforum.org/agenda/2020/04/coronaviruseducation-global-covid19-online-digital-learning/.

11 Law School Accreditation, A.B.A., https://www.americanbar.org/groups/legal_education/accreditation/ (last visited Oct. 1, 2020).

${ }^{12}$ Stephanie Francis Ward, Expanded Online Law School Classes Could Continue Under Plan Endorsed by ABA Legal Ed Council, A.B.A. J. (May 15, 2020, 4:45 PM), https://www.abajournal.com/news/article/ABA-Legal-Ed-approves-motion-for-rule-change-regardingshort-term-emergencies-nixes-request-to-suspend-bar-pass-standard. 
Education and Admissions to the Bar to permit law schools to expand online learning in response to the "extraordinary circumstances" posed by the COVID-19 pandemic. ${ }^{13}$ While these short-term measures will need to be approved and extended by the ABA during its Annual Meeting in August, ${ }^{14}$ it seems likely that the expansion of online learning will be allowed for the upcoming academic year. ${ }^{15}$ Notably, a number of law schools have been offering expanded online learning for quite some time under variations granted by the ABA. ${ }^{16}$ Mitchell Hamline School of Law received approval from the ABA in 2015 to offer a first-of-its-kind hybrid J.D. program, ${ }^{17}$ while at least eight other law schools have followed suit in obtaining ABA variances to expand the online component of their J.D. programs. ${ }^{18}$

The sudden transition to remote-learning during the spring semester, as well as to virtual legal practice, undoubtedly negatively impacted students' learning opportunities in various ways. Students not only had to manage the anxiety of learning during an unexpected pandemic, but also needed to quickly adapt to a new learning methodology implemented (sometimes awkwardly) by faculty in the middle of an academic semester. An additional troubling consequence of the pandemic has been a reduction (and often, elimination) of the opportunities for law students to obtain in-person experiential lawyering experiences off-campus. The ability of students to practically apply the lessons of law school in a real-world legal environment is crucial to their professional development, ${ }^{19}$ and law schools should take

${ }^{13}$ Id. ABA Standard 306 on "Distance Education" provides, in part, the following: "A law school may grant a student up to one-third of the credit hours required for the J.D. degree for distance education courses qualifying under this Standard. A law school may grant up to 10 of those credits during the first one-third of a student's program of legal education." ABA Standards \& Rules of Procedure for Approval of Law Schools (2019-2020), A.B.A., 19 (2019). As of August 2020, Standard 306 has been reserved and deleted. ABA Standards \& Rules of Procedure for Approval of Law Schools (2020-2021), A.B.A., 21 (2020).

${ }^{14}$ Ward, supra note 12.

${ }^{15}$ What is less clear is whether state bar accreditation standards will similarly allow law schools to expand online credit offerings.

${ }^{16}$ See generally Paul Caron, New Hampshire is Ninth Law School to Offer Hybrid Online J.D., First with IP Focus, TAXPROF BLOG (Mar. 14, 2019), https://taxprof.typepad.com/taxprof_blog/2019/03/new-hampshire-is-ninth-law-school-to-offer-hybridonline-jd-first-with-ip-focus.html; Blended Leaming at Mitchell Hamline, MITCHELl HAMLINE, https://mitchellhamline.edu/academics/j-d-enrollment-options/blended-learning-at-mitchell-hamline (last visited Oct. 1, 2020).

${ }^{17}$ See Blended Learning at Mitchell Hamline, supra note 16 (Mitchell Hamline's "blended learning" program combines online and in-person legal instruction).

${ }^{18}$ See generally Caron, supra note 16. Other law schools that have obtained ABA variances to offer a hybrid J.D. program (which increases the number of online credits a student may take for degree purposes) include the University of New Hampshire, the University of Denver Sturm College of Law, the Loyola University-Chicago School of Law, the Syracuse University College of Law, the Seton Hall University School of Law, Southwestern Law School, the University of Dayton School of Law, and the Touro College Jacob D. Fuchsberg Law Center. Id.

${ }^{19}$ See Mary Lynch, The Importance of Experiential Learning for Development of Essential Skills in Cross-Cultural and Intercultural Effectiveness, 1 J. EXPERIENTIAL LEARNING 129, 142-47 (2014) (describing the importance of experience-based learning opportunities for law school students). 
pains to re-envision how to replicate these experiences during the COVID19 era. One option may be for law schools to create opportunities for students to develop lawyering skills in online and hybrid formats (such as participation in online oral arguments, virtual client engagement, and so forth), given the move to online court adjudication and virtual legal practice. $^{20}$

There has also been a significant financial impact on law schools caused by the COVID-19 pandemic (and their parent universities, if any). ${ }^{21}$ The pandemic has necessitated that schools invest heavily in multiple COVID19-related safety precaution measures (and new technology), while preparing for potential decreases in both endowment draws (given the market instability caused in part by COVID-19) and tuition income. ${ }^{22}$ As a result, many law schools froze new hiring, ${ }^{23}$ instituted across-the-board salary decreases, ${ }^{24}$ and resorted to furloughing employees in response to the pandemic. ${ }^{25}$ Interestingly, law school applications have dramatically increased by $32 \%$ for the upcoming 2021-2022 academic year-spurred in part by the ongoing pandemic, increased interest in social and racial justice issues, and the death of United States Supreme Court Justice Ruth Bader Ginsburg. ${ }^{26}$

Despite the gloomy repercussions of the pandemic on legal education (and on education generally), it has created a rare opportunity for innovative law schools to reevaluate the traditional law school curriculum and

\footnotetext{
${ }^{20}$ See infra Part III (discussing the transition to online legal practice and dispute resolution).

${ }^{21}$ Karen Sloan, Law Schools Hit by Financial Fallout from COVID-19, LAW.COM (Apr. 23, 2020, 1:54 PM) [hereinafter Sloan, Financial Fallout], https://www.law.com/2020/04/23/law-schools-hit-byfinancial-fallout-from-covid-19.

${ }^{22}$ Id. See also Karen Sloan, Law Schools Expect Enrollment to Remain Steady Amid COVID-19, LAW.COM (July 28, 2020, 2:54 PM), https://www.law.com/2020/07/28/law-schools-expect-enrollmentto-remain-steady-amid-covid- 19 (explaining how, interestingly, experts are predicting that enrollment at most law schools will remain steady or increase for the 2020-2021 academic year).

${ }^{23}$ Sloan, Financial Fallout, supra note 21.

${ }^{24} I d$.

${ }^{25} \mathrm{Id}$.

${ }^{26}$ Scott Jaschik, Applications Jump to Law and Medical School, INSIDE HIGHER Ed (Nov. 30, 2020), https://www.insidehighered.com/admissions/article/2020/11/30/applications-jump-law-and-medicalschool (Law School Admission Concil President Kelly Testy noted that "[i]n times of economic instability, students are looking at law schools"); Staci Zaretsky, There's A Run on Law School, with Applicants and Applications WAY Up, ABOvE L. (Nov. 18, 2020, 12:12 PM), https://abovethelaw.com/2020/1 1/theres-a-run-on-law-school-with-applicants-and-applications-way-up/ (Law School Admission Council President Kelly Testy explained that "We are seeing a real surge in candidates taking the LSAT and applying. There are a lot of factors at work here. But we hear a lot of [sic.] about motivation from [Ruthe Bader Ginsburg]- the RBG moment. We've been saying our candidates have 'really big goals.' They are talking about racism, COVID, economic inequality, political polarization, and climate change. They are inspired to make a difference."); Karen Sloan, Law School Applicants Are Way Up. Is it an 'RBG Moment'?, LAW.COM (Nov. 17, 2020, 1:39 PM), https://www.law.com/2020/11/17/law-school-applicants-are-way-up-is-it-an-rbg-moment/ (opining that the death of U.S. Supreme Court Justice Ruth Bader Ginsburg may have contributed to increased interest in legal education).
} 
mission. ${ }^{27}$ The vast majority of reforms adopted by law schools for the upcoming 2020-21 year, however, seek to merely tweak the traditional model while not incorporating substantive changes. ${ }^{28}$ Many law schools may feel as if they do not have sufficient time to thoughtfully implement changes to the traditional model by the next academic year, while others may simply be hesitant to depart from classic law school methods. The COVID-19 law school initiatives anticipated for the 2020-21 year thus tend to focus on the method of instructional delivery: fully online models, hybrid models, and the traditional in-person residential model. ${ }^{29} \mathrm{~A}$ number of law schools, including Harvard Law School, the University of California, Berkeley School of Law, Vermont Law School, the University of Connecticut School of Law, the University of California Hastings College of Law, and Western Michigan Cooley Law School are planning on instituting a fully-online learning model for the upcoming academic year. ${ }^{30}$ These law schools based their decision on the potential health impacts on students, staff, and faculty of reopening a residential campus in the midst of a coronavirus pandemic ${ }^{31}$ By announcing their decisions to move instruction fully online at an earlier point in the summer, these schools also provided themselves with additional time to prepare to offer a more robust online-learning experience for students in the fall. ${ }^{32}$

The majority of law schools, however, are planning to adopt a compromise between in-person and online learning by adopting variations of a hybrid model of learning. ${ }^{33}$ These schools are likely motivated to offer a hybrid model for a range of reasons: to preserve the in-person benefits of law school instruction, to respond to student desires to offer residential opportunities, to create a sense of community, to aid admission efforts for the upcoming year, and to forestall a possible decrease in enrollment and tuition revenue. Law schools adopting the hybrid model are investing resources not only in improving their technological capabilities to offer expanded online courses, but also are incorporating measures (such as

\footnotetext{
${ }^{27}$ With that said, law schools should focus on meaningful and thoughtful pedagogical reform rather than resort to the allure of market-based "disaster capitalism" initiatives. See, e.g., NAOMI KLEIN, THE SHock Doctrine: The RiSe of Disaster CAPITALISM 6 (2007) (examining how the forces of free market capitalism have historically exploited the societal "shocks" caused by crisis events to increase wealth and income inequality).

28 See, e.g., Alb. L. SCH., RETURN to CAMPUS Plan (June 29, 2020), https://www.albanylaw.edu/coronavirus/Documents/2020-06-Return-to-Campus-Plan.pdf (depicting Albany Law School's temporary changes to combat COVID-19).

${ }^{29}$ Vijay Govindarajan \& Anup Srivastava, A Post-Pandemic Strategy for U.S. Higher Ed, HARV. BUS. REV. (June 2, 2020), https://hbr.org/2020/06/a-post-pandemic-strategy-for-u-s-higher-ed.

${ }^{30}$ See Sloan, Online or in Person?, supra note 7.

${ }^{31} \mathrm{Id}$.

${ }^{32}$ See Karen Sloan, Harvard Law Will Remain Online-Only for Fall Semester, LAW.COM (June 3, 2020, 6:20 PM), https://www.law.com/2020/06/03/harvard-law-will-remain-online-only-for-fallsemester/.

${ }^{33}$ See Sloan, Online or in Person?, supra note 7 (the hybrid model adopted by many law schools allows students [and at times, faculty and staff] to elect either an in-person or remote-learning option).
} 
social-distancing and face-mask requirements, improved ventilation, smaller class sizes in larger classrooms, and restrictions on on-campus events and faculty travel) intended to minimize the COVID-19 health risks associated with indoor settings. ${ }^{34}$ It is, however, highly questionable whether any school will be able to fully eliminate the health risks of in-person instruction as more information about COVID-19 becomes available. ${ }^{35}$

Many of these law schools will focus on providing in-person courses for their incoming $1 \mathrm{~L}$ student classes while allowing expanded online courses for $2 \mathrm{~L}$ and $3 \mathrm{~L}$ students - on the basis that the community and relationship building that takes place during the first year of law school is particularly critical for new students. ${ }^{36}$ For example, my own institution, Albany Law School, is allowing students the option to take courses in a residential format, a fully online format, or a hybrid format. ${ }^{37}$ Indiana University, Maurer School of Law will also offer a hybrid approach for the upcoming academic year. ${ }^{38}$ While its $2 \mathrm{~L}$ and $3 \mathrm{~L}$ students will be given options to take either in-person or online courses similar to Albany Law School, Indiana Law has adopted an innovative block scheduling format for all incoming $1 \mathrm{~L}$ students. ${ }^{39}$ Under this model, $1 \mathrm{~L}$ students will take a single course in a concentrated four-week time period (or "block") (followed immediately by a final exam), before taking the next traditional $1 \mathrm{~L}$ course in a four-week block: ${ }^{40}$

${ }^{34}$ See ALB. L. SCH., supra note 28, at 12-13; Austen Parrish, Indiana Law's Fall 1 L Program (170), LEGAL EVOLUTION (June 18, 2020), https:/www.legalevolution.org/2020/06/indiana-laws-fall-11program-170/ (Indiana University Maurer School of Law, for example, adopted a block scheduling framework for first-year classes that combined both on-line and in-person learning); Sloan, Online or in Person?, supra note 7 (noting that the majority of law schools are adopting a mix of on-line and inperson learning).

${ }^{35}$ See Adrienne LaFrance, This Push to Open Schools is Guaranteed to Fail, ATLANTIC (Aug. 2, 2020), https://www.theatlantic.com/ideas/archive/2020/08/push-reopen-schools-fail/614869/ (citing the conclusions of epidemiologists that COVID-19 transmission in educational settings is inevitable); Daria Roithmayr, Gregg Gonsalves, Anthony Paul Farley, Keeanga-Yamahtta Taylor, \& Eduardo BonillaSilva, Universities Should Stay Closed to Protect Workers of Color, Bloomberg L. (June 25, 2020, 4:01 AM), https://news.bloomberglaw.com/us-law-week/insight-universities-should-stay-closed-to-protectworkers-of-color (arguing that a return to in-person instruction will disproportionately expose workers of color to COVID-19 health risks).

${ }^{36}$ See ALB. L. SCH., supra note 28, at 12-13 (noting the educational and socio-emotional benefits of in-person learning); Parrish, supra note 34 (providing students with both in-person and online learning options). As stated by UC-Irvine Dean Song Richardson, "[i]t's not so much about the teaching. . [i]t's about continuing to help them enter our community and feel a part of it. We are hearing our 1Ls expressing a desire to see each other. If we can accommodate them and help build community that way, we'd like to try and do that." Sloan, Online or in Person?, supra note Error! Bookmark not defined.

${ }^{37}$ See ALB. L. SCH., supra note 28, at 12-13. Albany Law School is also allowing faculty to opt for in-person or remote instruction. $I d$. at 5 .

${ }^{38}$ See Parrish, supra note 34.

${ }^{39}$ See id.

${ }^{40}$ See id. (notably, students will continue to take both Legal Research and Writing and online Legal Profession courses concurrently with the "block" courses during the semester). 


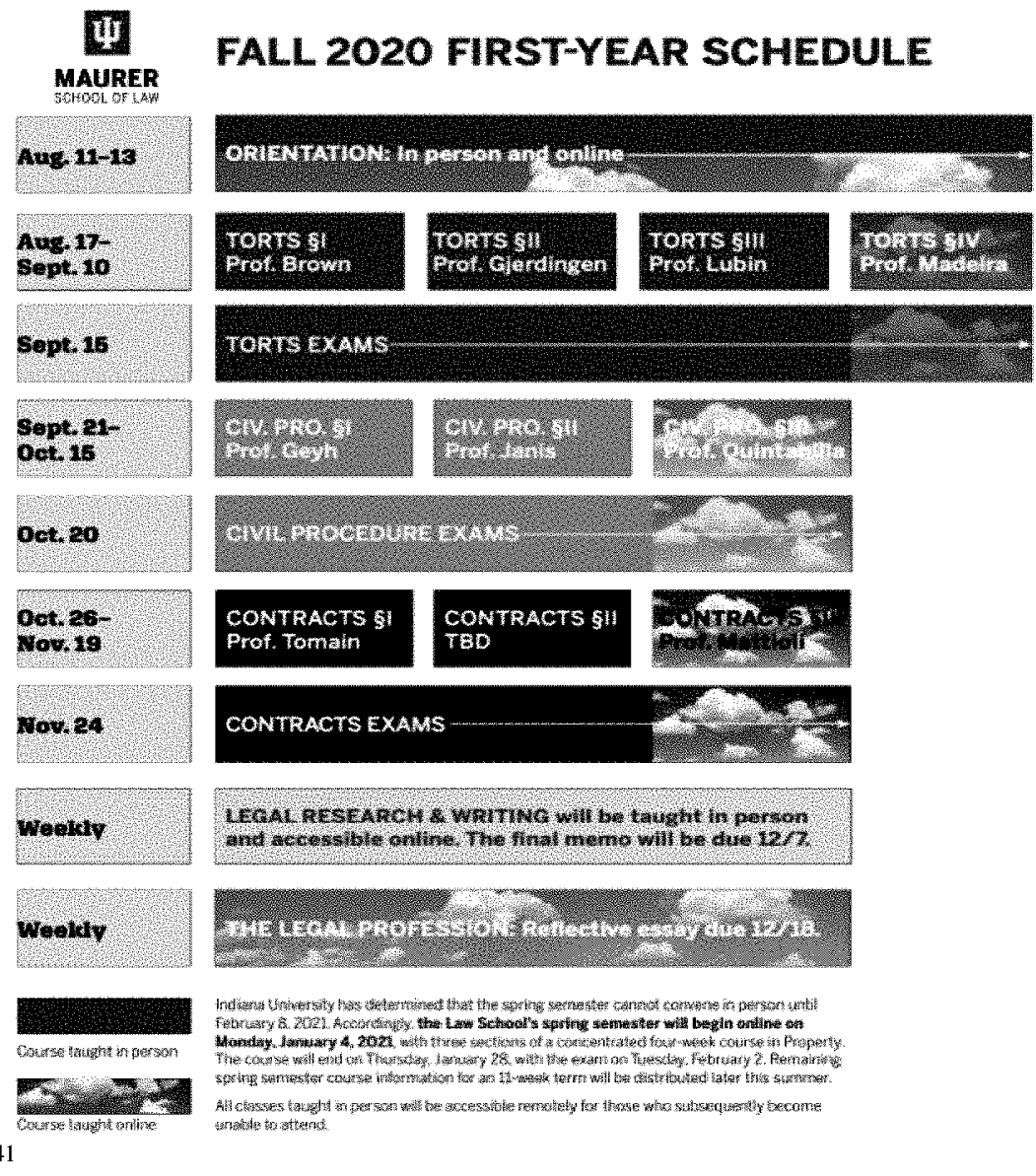

Law schools that are allowing some extent of in-person residential instruction generally have provided students (and sometimes faculty and staff) with a fully virtual option if individuals are concerned with returning to campus in the midst of a pandemic. ${ }^{42}$ The specific teaching methodologies that law schools will use to advance online learning during the 2020-21 academic year is less than clear. While the majority of law schools will likely use a blend of asynchronous and synchronous online course offerings, ${ }^{43}$ there has been frustratingly little information concerning the manner and methods in which faculty will modify their pedagogy to an online format.

${ }^{41} I d$.

${ }^{42}$ See, e.g., id. (acknowledging that "[ $\left.\mathrm{t}\right]$ he plan recognizes that students' personal circumstances could change during the semester. If they do, and students find that switching to online from in-person learning (or vice versa) is more beneficial, the plan will enable them to do so").

${ }^{43}$ See ALB. L. SCH., supra note 28, at 11, 20-21 (for example, my law school is offering a variety of both in-person and online courses during the 2020-2021 academic year); See Sloan, Online or In Person?, supra note 7 (noting that most law schools are offering both in-person and remote-learning options). 
There is, of course, a growing literature on effective online teaching methodologies in law school courses that should inform future efforts to transition to online learning. ${ }^{44}$

While faculty should absolutely retain the academic freedom to teach their courses in the manner they feel best supports students, our teachers also "need - and their students deserve-support and training not simply to teach online, but to teach well online."45 Law schools hopefully will continue to recognize the need for robust professional development focused on online teaching methodology. ${ }^{46}$

\section{SOCIAL JUSTICE ACTIVISM AND LAW SCHOOLS}

The COVID-19 pandemic has also exposed long-simmering issues of racial justice and inequality. ${ }^{47}$ The police killings of George Floyd, Ahmaud Arbery, and Breonna Taylor have sparked law students and faculty to demand structural changes to the traditional law school model. ${ }^{48}$ In particular, Black Law Students Associations (BLSAs), Latino Law Students Associations (LLSAs), and allied students at law schools throughout the nation are asking to transform legal education through (a) a re-envisioning of the core curriculum to address racial justice issues in required and elective courses; (b) the integration of racial justice courses in the first-year curriculum; (c) the offering of racial justice concentrations and certificate programs; (d) the creation of Racial Justice Centers, Institutes and Clinics; and (e) the hiring and retention of more BIPOC tenure-track and tenured

${ }^{44}$ See, e.g., Yvonne Dutton, Margaret Ryznar \& Kayleigh Long, Assessing Online Learning in Law Schools: Students Say Online Classes Deliver, 96 DENV. L. REV. 493, 519-29 (2019) (discussing empirical findings on the success of online teaching methods in law school); Yvonne M. Dutton \& Seema Mohapatra, COVID-19 and Law Teaching: Guidance on Developing an Asynchronous Online Course for Law Students, ST. LoUIS U. L.J. (forthcoming 2021) (manuscript at 12-13) (addressing best practices for developing effective online asynchronous courses); Charles Hodges, Stephanie Moore, Barb Lockee, Torrey Trust \& Aaron Bond, The Difference Between Emergency Remote Teaching and Online Learning, EDUCAUSE REV. (March 27, 2020), https://er.educause.edu/articles/2020/3/the-difference-betweenemergency-remote-teaching-and-online-learning (discussing effective online learning modalities); Nina A. Kohn, Teaching Law Online: A Guide for Faculty, J. LEGAL EDUC. (forthcoming 2020) (manuscript at 3) (providing suggestions on effective online synchronous and asynchronous teaching methods); Debora L. Threedy \& Aaron Dewald, Re-conceptualizing Doctrinal Teaching: Blending Online Videos with In-Class Problem-Solving, 64 J. LEGAL EDUC. 605, 615 (2015) (discussing the benefits of integrating problem-solving exercises in online courses); Best Practice Recommendations of Distance Learning for Legal Education 2.0, WORK GRP. DISTANCE LEARNING FOR LEGAL EDUC. (2015) https://lawprofessors.typepad.com/files/bestpracticerecommendationsfordistancelearningforlegaleducat ion-2015.pdf (discussing best practices for online learning in legal education).

${ }^{45}$ Kohn, supra note 44, at 3.

${ }^{46} I d$.; ALB. L. SCH., supra note 28, at 12-13.

${ }^{47}$ See Sloan, "This is the Civil Rights Movement of My Lifetime", supra note 6 (addressing how the pandemic has fueled racial justice protests).

${ }^{48}$ See Keyes, supra note 6; O'Brien, supra note 6; Sloan, "This is the Civil Rights Movement of My Lifetime", supra note 6; STETSON UNIV., supra note 6; Jibril et al., supra note 6. 
faculty ${ }^{49}$ Law students from over forty-five student organizations attending at least seventeen law schools in New York, Connecticut, and New Jersey alone have made demands that their law schools incorporate additional racial justice programming in the curriculum while prioritizing BIPOC faculty hiring and retention. ${ }^{50}$ The open letter published by these students seeks a number of changes to the traditional law school model, including:

- An expansion of "financial and programmatic resources for public interest education, criminal defense training, and critical race theory curriculum", 51

- An increase of "the number of Black faculty and faculty of color who are engaged in critical legal theory, interdisciplinary practice, and a radical imagination of the law beyond confinement and punishment",52

- A commitment "to increase Black, Indigenous, Latinx, and other students of color (especially those who are firstgeneration) in your classrooms through rigorous recruitment, scholarships, and race and equity programming", .53 and

- The offering of "immediate and practical trainings for students . . . [to] effectively advocate for protestors, organizers, and people on and off the streets subjected to state violence." 54

We should commend our students for courageously identifying the ways in which the traditional law school model is failing to prepare the modern generation of law graduates. Their stories and interactions with our law school communities matter:

- "[The] core curriculum strips the identity of marginalized students by disregarding the way they are treated differently in the justice system"

- "As a woman of color, every day I walk into class and I feel invalidated by the lack of discussion on the history

\footnotetext{
${ }^{49}$ See Keyes, supra note 6; O'Brien, supra note 6; Sloan, “This is the Civil Rights Movement of My Lifetime", supra note 6; STETSON UNIV., supra note 6; Jibril et al., supra note 6.

${ }^{50}$ Sloan, "This is the Civil Rights Movement of My Lifetime", supra note 6.

51 Eman Bare, Open Letter to Our Law School Deans, MEDIUM (June 14, 2020), https://medium.com/@eman.bare/open-letter-to-law-school-deans-fd6d621bceab.

${ }^{52} I d$.

${ }^{53} \mathrm{Id}$.

${ }^{54} \mathrm{Id}$.

${ }^{55}$ O'Brien, supra note 6.
} 
[of] racism and discrimination of my community in the system of law", 56

- "I am tired of acting like the law isn't oppressive and demand all law professors at UW to be trained to facilitate class discussions where there are racist undertones in our cases"; 57

- "We have fought for town halls and meetings with our deans to address the lack of BIPOC faculty, the absence of a critical race theory curriculum, and the general day-today racism we face from our peers, professors, and administrators", 58

- "We need a lot more than, 'Black students: We see you. We're here for you.' ... We need action to change the experience of black people and other people of color"',59

- "It feels like we're ignoring the ethics of what is happening right now and choosing to see it as political instead. It has been three weeks now of protests, and the fact that not a single law school has really done anything outside of a reading list and a town hall-I don't think they're going to."60

The strident calls to address racial inequality in education are being made not just for law schools, but for colleges and universities throughout the nation. ${ }^{61}$ As one student noted, "“[t]his is the civil rights movement of my lifetime." "'62

Of critical importance, a large number of law school faculty and deans petitioned the ABA in August 2020 to adopt a new accreditation requirement whereby every law school must incorporate required antiracist, bias, and cultural competency courses into its curriculum. ${ }^{63}$ The ABA's proposal to create a task force to explore these issues is as follows:

\footnotetext{
${ }^{56} I d$.

${ }^{57} \mathrm{Id}$.

${ }^{58}$ Jibril et al., supra note 6.

${ }^{59}$ Sloan, "This is the Civil Rights Movement of My Lifetime", supra note 6.

${ }^{60} \mathrm{Id}$.

${ }^{61}$ See, e.g., Greta Anderson, Organizing for Change: Students at Rice University and Colleges Across the U.S. are Seeking Ways to Leverage the Wealth and Connections of their Universities to Combat Racial Injustice, INSIDE HIGHER ED, (June 9, 2020, 3:00 AM), https://www.insidehighered.com/news/2020/06/09/students-organize-racial-justice-campus-and (discussing the national student movement to address racial justice issues at colleges and universities); Anne Dennon, Students Demand Racial Justice and Equity On Campus, BEST COLLs. (June 17, 2020), https://www.bestcolleges.com/blog/college-student-activists-black-lives-matter/ (addressing student demands to respond to racialized police violence, increase campus diversity, and increase racial justice curricular offerings).

${ }^{62}$ Sloan, "This is the Civil Rights Movement of My Lifetime", supra note 6.

${ }^{63}$ ABA Proposal to Create Task Force on Inclusion of Bias and Cultural Competency Courses (August 3, 2020) (on file with author).
} 
We hope that the ABA believes that every law student should be educated with respect to bias, cultural awareness/competence, and anti-racism - these are important parts of professional competence and an important part of being a lawyer. Every law school should be required to develop curricula and training. It is for each law school to decide the specifics and contents of this course(s) and how to satisfy this requirement.

In this way, every law student would ultimately receive training and education around bias, cultural competence, and anti-racism as this is an important part of lawyering and practice. But the specific contracts of such courses would not be mandated by the American Bar Association, rather the fact of receiving such an education would be mandated.

We therefore urge the creation of an ABA Taskforce to consider enacting a requirement that every law school must have bias, and cultural competence/awareness, and anti-racist curricula specific to each school. ${ }^{64}$

A number of law school deans and American Association of Law School ("AALS") sections have supported the ABA Proposal (including the AALS Section on Minority Groups, of which I am currently the Chair).$^{65}$ Law schools would be well-advised to re-envision the traditional law school model by thoughtfully incorporating racial justice and bias issues in their curriculum. The traditional approach to legal education tends to minimize the role of race and bias in the formation of American law. ${ }^{66} \mathrm{Law}$ in the firstyear curriculum in particular is historically taught in a neutral, detached, and decontextualized casebook methodology, which can result in a failure to address issues of social oppression and discrimination in the classroom. ${ }^{67}$ The failure to address bias in the classroom tends to reproduce hierarchies in legal education by presenting the "law" as equal and neutral without taking into account the many ways in which "law" has and can be used to support racial and social inequality and subordination. ${ }^{68}$ The failure to address bias in the classroom also undermines the intercultural effectiveness and professional readiness of law students (often a requirement of state bar associations) by not fully preparing students to practice in a diverse world,

\footnotetext{
${ }^{64} \mathrm{Id}$.

${ }^{65} \mathrm{Id}$.

${ }^{66}$ See Paul Caron, Harvard Rising 2Ls: Law Schools' Complicity on Racism Must Be Challenged, TAXPROF BLOG (June 25, 2020), https://taxprof.typepad.com/taxprof_blog/2020/06/law-schoolscomplicity-on-racism-must-be-challenged.html (arguing that law schools are obligated to address issues of racial inequality in its curriculum and hiring practices).

${ }^{67}$ See id. (noting how issues of race traditionally are obscured in law school courses).

${ }^{68}$ See generally RichARD ROTHSTEIN, THE COLOR OF LAW: A FORGOTTEN HISTORY OF HOW OUR GOVERNMENT SEGREGATED AMERICA (2017) (arguing that segregation is a byproduct of explicit government policies at the local, state, and federal levels).
} 
which is especially important given that many states include a "competency and professional values" requirement for admission to the Bar. ${ }^{69}$

The need to re-envision the traditional law school curriculum in order to thoughtfully integrate issues of social bias is underscored by changing demographics in law school enrollment. Female and minority enrollment in law schools has significantly increased since the Langdellian case-method approach came to define the traditional law school curriculum, ${ }^{70}$ in no large part due to the pervasive discrimination exercised against persons who were not white, upper-class, cis-gendered, heterosexual men for most of legal education's history. ${ }^{71}$ Whereas women accounted for only $9 \%$ of law students in 1970, women now constitute the majority of law students. ${ }^{72}$ The enrollment of racial minorities has also grown significantly over the last many decades. While minority students made up only $9 \%$ of first-year J.D. enrollments in 1978, the percentage of minority students enrolled in J.D. programs has increased to $31 \%$ by $2019 .^{73}$ These trends mirror changing national racial demographics, as the United States is expected to become "majority minority" in just twenty-five years. ${ }^{74}$

Perhaps unsurprisingly, these demographic shifts seem to correspond with renewed student interest in social justice issues. One of the reasons for attending law school that was most cited by prospective and current law students was to become prepared to "advocate for social change" through the law. ${ }^{75}$ A required $1 \mathrm{~L}$ course focused on issues in race, bias and the law will likely be adopted by innovative law schools in the near future, and law schools should take seriously the demands of many of our Black and Brown students (and allies) to increase the number of courses offered that focus on racial justice (perhaps leading to a Racial Justice Concentration and/or

${ }^{69}$ See, e.g., Skills Competency Requirement and Professional Values Bar Admission Requirement, N.Y.ST. BD. L. EXAM'RS, https:/www.nybarexam.org/Skills/skills.htm (providing an example of a state with such requirements prior to the Bar) (last visited Nov. 25, 2020); Mary A. Lynch, Robin Boyle, Rhonda V. Magee, \& Antoinette Sedillo Lopez, Teaching the Newly Essential Knowledge, Skills, and Values in a Changing World, Section E: Intercultural Effectiveness 1 (Alb. L. Sch. Working Paper, Paper No. 10 for 2015-16), https://papers.ssrn.com/sol3/papers.cfm?abstract_id=2558863 (arguing that law schools "should more effectively help students examine how legal structures can ignore, silence, and devalue alternative perspectives and diverse identities").

${ }^{70}$ See Robert W. Gordon, The Geologic Strata of the Law School Curriculum, 60 VAND. L. REV. 339, 340-41 (2007) (providing historical context as to how the case-method approach came to dominate traditional American legal education); ABA Profile of the Legal Profession 2020, A.B.A. 58 (2020), https://www.americanbar.org/content/dam/aba/administrative/news/2020/07/potlp2020.pdf (discussing how female and minority enrollment in law schools have increased dramatically in the last few decades).

${ }^{71}$ A.B.A., supra note 70 , at 58 .

${ }^{72}$ Id. Women became the majority of law students in ABA-accredited law schools for the first time in 2016 (50.3\% of all JD students). The percentage increased to $53.3 \%$ of all J.D. students by $2019 . I d$.

${ }^{73} \mathrm{Id}$.

${ }^{74}$ William H. Frey, The US Will Become "Minority White" in 2045, Census Projects, BRoOKINGS INST. (Mar. 14, 2018), https://www.brookings.edu/blog/the-avenue/2018/03/14/the-us-will-becomeminority-white-in-2045-census-projects/.

${ }^{75}$ A.B.A., supra note 70 , at $57.32 \%$ of prospective and current J.D. students cited the ability to "advocate for social change" as a key motivation for attending law school. Id. 
Certificate) ${ }^{76}$ The law school of the future should further respond to these social and demographic trends by prioritizing the hiring and retention of diverse BIPOC faculty. ${ }^{77}$

\section{TECHNOLOGICAL DisRUPTION IN LEGAL EDUCATION AND PRACTICE}

Legal education and practice are also being influenced by technological innovations in artificial intelligence, predictive analytics, and virtual conferencing. The disruption of law by emerging technologies has been accelerated by the COVID-19 pandemic-which has led lawyers, professors, and students to abruptly transition to online teaching, remote dispute resolution, and the virtual representation of clients. ${ }^{78}$

Law firms and lawyers across the world are integrating law-based artificial intelligence systems into their practice to improve efficiency and the delivery of lower-cost basic legal services to clients. ${ }^{79}$ Of particular note, JP Morgan has begun using a cloud-based machine-learning program called Contract Intelligence ("COIN") to complete massive document review projects in mere seconds that would have otherwise required 360,000 hours of human labor. ${ }^{80}$

Artificial intelligence has also been implemented in the area of "knowledge management" and predictive legal research. ${ }^{81}$ The global law firm BakerHostetler, for example, is using the machine-learning program ROSS (created by IBM) to allow lawyers to obtain answers to legal issues

\footnotetext{
${ }_{76}$ See, e.g., Critical Race Studies J.D. Specialization, UCLA L., https://www.law.ucla.edu/academics/degrees/jd-program/specializations/critical-race-studies-jdspecialization [https://perma.cc/TF3N-PZAV] (last visited July 29, 2020); Race and Law Certificate, BERKELEY L., https://www.law.berkeley.edu/research/thelton-e-henderson-center-for-socialjustice/race-and-law-certificate/ [https://perma.cc/BD7K-CCHT] (last visited July 29, 2020); Race and Law: Courses and Seminars, UNIV. VA. SCH. L., https://www.law.virginia.edu/academics/concentrations\#race [https://perma.cc/L7KU-LDL2] (providing a few examples of Racial Justice certificates or concentrations currently offered at law schools) (last visited July 29, 2020).

${ }^{n}$ An AALS proposal to survey the racial diversity of law school faculties is forthcoming from a diverse group of faculty members. The proposal is on file with the Author, and is expected to be submitted during the 2020-21 academic year.

${ }^{78}$ See, e.g., LEGAL EXEC. INST., Law Firm Updates: COVID-19's Impact on the Business of Law, THOMSON REUTERS (July 20, 2020), https://www.legalexecutiveinstitute.com/law-firm-updates-covid19/ (providing updates on the impact of COVID-19 on law); SUSSKIND, supra note 2, at xviii-xix (predicting fundamental and irreversible changes in the world of law).

79 Erin Winick, Lawyer-Bots are Shaking Up Jobs, MIT TECH. REV. (Dec. 12, 2017), https://www.technologyreview.com/2017/12/12/105002/lawyer-bots-are-shaking-up-jobs/.

${ }^{80}$ Id.; Hugh Son, JP Morgan Software Does in Seconds What Took Lawyers 360,000 Hours, BLOOMBERG, https:/www.bloomberg.com/news/articles/2017-02-28/jpmorgan-marshals-an-army-ofdevelopers-to-automate-high-finance (Feb. 28, 2017, 7:24 AM).

${ }^{81}$ IBM Cognitive Business, How Watson Helps Lawyers Find Answers in Legal Research, MEDIUM (Jan. 4, 2017), https://medium.com/cognitivebusiness/how-watson-helps-lawyers-find-answers-in-legalresearch-672ea028dfb8.
} 
by asking the ROSS system a simple question. ${ }^{82}$ Other algorithmic technologies have been developed to generate legal research from a scanned legal brief, ${ }^{83}$ draft contracts, and other transactional documents, ${ }^{84}$ and provide assistance with resolving basic legal problems. ${ }^{85}$

Advancements in technology have additionally impacted the very nature and location of legal practice, facilitating the growth of outsourcing, contract labor, virtual representation, and on-demand subscription legal services. ${ }^{86}$ Law firms have greatly expanded the ability of lawyers to work remotely over the last few years, reducing the costs of maintaining physical office space while promoting flexibility for its attorneys and staff. ${ }^{87}$ Some law firms are even considering making the transition to remote lawyering permanent. ${ }^{88}$ This trend will undoubtedly be accelerated as law schools similarly transition to online teaching methodologies in the wake of the COVID-19 pandemic.

There has also been an interesting move to online courts and "online

82 Amit Chowdhry, Law Firm BakerHostetler Hires a 'Digital Attorney' Named ROSS, FORBES (May 17, 2016, 6:59 PM), https://www.forbes.com/sites/amitchowdhry/2016/05/17/law-firmbakerhostetler-hires-a-digital-attorney-named-ross/\#2150efe178c4.

${ }^{83}$ For example, the CaselQ system feeds the search result information "into a complex predictive algorithm that leverages the archived intelligence of legal experts who've explored these issues previously to compile a list of highly relevant case laws, thereby highlighting potential missing points of law, or alternative arguments not appraised prior." CaseMine Features, CASEMINE https://www.casemine.com/home/guide (last visited Oct. 3, 2020).

${ }^{84}$ Kane Fulton, Founder Facing a Legal Problem? Call in Robot Lawyer LISA, TECH NATION, (Mar. 8, 2019), https://technation.io/news/founder-facing-a-legal-dispute-call-in-robot-lawyer-lisa/; KIRA, https://kirasystems.com/ (last visited Oct. 3, 2020).

${ }^{85}$ For example, automated "lawyer-bots," such as DoNotPay-which helps people, among other things, sue agencies and contest parking tickets-are quickly proliferating. DONOTPAY, https://donotpay.com/ (last visited Oct. 3, 2020).

${ }^{86}$ See Michael D. Bell, The Electronic Lawyer: Technology and Outsourcing, 72 TEX. B.J. 542, 542 (2009) (discussing outsourcing in the legal profession); Danielle Braff, One Size Does Not Fit All: Law Firm Subscription Plans Come in All Shapes and Sizes, A.B.A. J. (July 1, 2019, 9:08 AM), https://www.abajournal.com/web/article/law-firm-subscriptions (exploring the increase in on-demand legal subscription services); Daniel S. Wittenberg, The Virtual Practice of Law, ABA (March 22, 2017), https://www.americanbar.org/groups/litigation/publications/litigation-news/business-litigation/thevirtual-practice-of-law/ (addressing the rise in virtual lawyering).

${ }^{87}$ See, e.g., Allison Deerr, BigLaw Embraces the Remote Work Trend, A.B.A. J. (Aug. 1, 2017, 2:00

https://www.abajournal.com/magazine/article/biglaw_remote_flexible_workplace_telecommute (discussing how many large law firms have increased the opportunities for lawyers to work remotely); Lyle Moran, Business as [Un]usual: Will the COVID-19 Pandemic Fundamentally Remake the Legal Industry?, 106 A.B.A. J. 34, 37 (2020) (addressing the impact of COVID-19 on virtual legal practice); Brenda Sapino Jeffreys, Legal Professionals Want to Keep Working from Home, but Will That Last?, LAw.COM (June 11, 2020, 4:36 PM), https://www.law.com/americanlawyer/2020/06/11/legalprofessionals-want-to-keep-working-from-home-but-will-that-last/ (citing a study that $67 \%$ of lawyers and staff would prefer to continue working remotely once the pandemic ends).

${ }^{88}$ Roy Strom, This Big Law Firm Has Permanent Plans for Remote Working, BLOOMBERG L. (July 16, 2020, 4:56 AM), https://news.bloomberglaw.com/business-and-practice/this-big-law-firm-haspermanent-plans-for-remote-working. 
dispute resolution," ${ }^{99}$ fueled in part by access to justice and efficiency concerns. The transition to online dispute resolution began well before the COVID-19 pandemic and yet certainly has been accelerated by the current need to administer our complex judicial system in a virtual and contact-less manner. ${ }^{90}$ Even the ludditious United States Supreme Court held virtual oral arguments (albeit via teleconference) for the first time ever this past May, ${ }^{91}$ while other courts in the United States and beyond have begun experimenting with online resolution of disputes. ${ }^{92}$ The influential legal futurist Richard Susskind has predicted in his new book Online Courts and the Future of Justice that the accelerating advancement of technology, combined with the dire need to increase low-cost access to the judicial system, will lead to a great expansion of online courts and virtual dispute resolution tribunals. ${ }^{93}$ Susskind envisions a near future when both evidence and legal arguments can be submitted to courts online. ${ }^{94} \mathrm{He}$ believes that the second generation of legal technology could eventually lead to courts' becoming akin to a sophisticated diagnostic system, which would rely on outcome predictive analytics to make case-outcome predictions and "holdings" based on previous court decisions (i.e. precedent). ${ }^{95}$

The recent emergence of artificial intelligence technologies, however, has also been seen as a threat to the future of legal education and law practice, with concerns that such technologies tend to embed the social biases of their coders while automating the functions of lawyers ${ }^{96}$ Emerging machine-learning and predictive technologies are often seen as an existential threat to both legal practice and education, potentially eliminating the need for (human) lawyers to perform certain tasks and services (such as basic

89 Meredith McBride, ODR in the Era of COVID-19, A.B.A. (Oct. 27, 2020), https://www.americanbar.org/groups/family_law/committees/alternative-dispute-resolution/odr/.

${ }^{90} \mathrm{Id}$.

${ }^{91}$ Josh Gerstein, Vinus Prompts First-ever Arguments by Phone at Supreme Court, POLITICO (May 4, 2020, 1:11 PM), https:/www.politico.com/news/2020/05/04/coronavirus-supreme-court-arguments234186.

92 Richard Susskind, OnLine Courts AND the Future of Justice 7, 14 (2019). See also JoINT Tech. Comm. eT AL., JTC Resolrce Bulletin: Case Studies IN ODR For Courts 1 (Version 2.0, Jan. 28, 2020), https://www.ncsc.org/_data/assets/pdf_file/0020/16517/2020-01-28-odr-case-studiesv2-final.pdf [https://perma.cc/CR5K-DCZN] (stating that "[s]ince 2016, the shift in US courts' practical experience as well as interest in [online dispute resolution] has been seismic. Dozones, if not hundreds of courts from large and small jurisdictions all over the US have online dispute resolution implements for some case types and are looking for ways to expand use"); U.S. CTS., Coronavirus (COVID-19): Response and Recovery (July 2, 2020), https:/www.uscourts.gov/news/2020/07/02/coronavirus-covid19-response-and-recovery (providing regular updates on federal court responses to COVID-19, including an increase in virtual court services).

${ }^{93}$ SUSSKIND, supra note 92.

${ }^{94} \mathrm{Id}$. at 101 .

${ }^{95} I d$. at 281 .

${ }^{96} \mathrm{Id}$. at 179-80; Meredith Whittaker et. al., AI Now Report 2018, AI Now INST. 3, 42 (Dec. 2018), https:/ainowinstitute.org/AI_Now_2018_Report.pdf (noting that "[t] there are harms and biases in A.I. systems. That debate has been settled: the evidence has mounted beyond doubt ... [and] [t] he next task now is addressing these harms"). 
legal research, the drafting of basic legal instruments, etc.) while negatively impacting legal employment opportunities. ${ }^{97}$

We cannot stop the march of the lawyer-bots, but we can do our best to prepare students for the newly emerging techno-legal landscape. Law schools should thus strive to prepare students to practice law in the new AIenabled technological world by considering both curricular change and program development.

\section{CONCLUSION}

This article has been a contemplation on the future of law schools in the midst of multiple agents of change: the COVID-19 pandemic, technological disruption, and growing racial justice awareness. I hope to contribute to the burgeoning national discussion by sharing my thoughts on how these structural changes will (and perhaps should) impact the law school of the future, while offering suggestions for future law school innovations.

There are a number of social and technological forces that will likely continue to impact both legal education and practice in the very near future:

- There will be a much stronger transition to hybrid online learning at the vast majority of law schools. The shift to online learning methodologies has already been facilitated by technological disruption and the need to decrease costs at many law schools (whether due to decreased enrollment, higher tuition discount rates, or other factors). The COVID-19 pandemic will surely hasten the adoption of online teaching at most law schools, especially now that most law schools will be offering expanded online options until the COVID-19 pandemic has been mitigated (which means at least until the year 2022).

- The trend to online learning will also be facilitated by a growing transition to "online courts" and virtual dispute resolution methodologies adopted by state and federal tribunals throughout the country and world. It is unlikely, however, that online learning will completely displace in-person residential programs. The pandemic has exposed both the potential value and the clear shortcomings of online learning within the unique context of legal education. ${ }^{98}$ The ABA will almost

\footnotetext{
${ }^{97}$ See, e.g., SUSSKIND, supra note 2, at 185 (predicting fundamental and irreversible changes in the world of law).

${ }^{98}$ Charlie Dunlap, Guest Post: "Is Remote Learning the Future of Legal Education?", LAWFIRE (May 14, 2020), https://sites.duke.edu/lawfire/2020/05/14/guest-post-is-remote-learning-is-the-futureof-legal-education/ [https://perma.cc/M4QR-VYW5].
} 
certainly continue to loosen restrictions on online learning: both as an emergency response to the ongoing pandemic and as a permanent response to the continuing technological shifts in law practice. I suspect that the "variances" that many law schools have obtained through the ABA to offer hybrid online J.D. programs will be become normalized through modifications (or new interpretations) to ABA Standard 306 on Distance Education.

- There will also likely be continued calls for a wholesale re-envisioning of the traditional law school model, with a particular focus on curricular change, expanded experiential opportunities, and social and racial justice. The aforementioned ABA Proposal to create a Task Force on adding an accreditation requirement that requires law schools to incorporate courses on antiracism, bias and cultural competencies will likely receive significant support from law school deans and faculty around the country, leading many schools to reevaluate their current curricular offerings.

The perfect storm of the COVID-19 pandemic, technological change, and renewed attention to social justice issues will also likely lead law schools to further engage in deep conversations concerning the future of legal education. Based on these interrelated forces, I posit that the law school of the future will need to ensure that students are being prepared to:

- Engage in high-level critical analysis. This will involve focusing on students' ability to develop, understand, and articulate policy arguments, engage in complex oral and written advocacy, and appreciate theoretical explications of the law. Such skills are unlikely to be displaced by technological innovation and law-based artificial intelligence tools any time soon. This is supported by a review of court litigation concerning what it means to "practice law" in the machine-learning context: courts have tended to make a distinction between the use of legal analysis and independent judgment (finding that this weighs in favor of finding that a person is practicing law) as opposed to engaging in tasks that could be 
performed by legal technologies (finding that this weighs in favor of finding that a person is not practicing law). ${ }^{99}$

- Exercise independent judgment in the analysis of legal problems. This may involve intentionality with respect to providing students with multiple opportunities to independently make decisions during law school (such as through motion exercises, simulations, and clientcounseling). As noted earlier in this Article, many futurists (and courts defining what it means to "practice law") believe that this will be one of the key human abilities that will not be displaced by emerging technology in the future.

- Provide creative solutions to complicated multidisciplinary problems. This may involve preparing students to provide individualized advice to clients and engaging in interdisciplinary group problem-solving activities. These are also higher thinking skills that will not be so easily replaced by emerging technologies.

- Provide emotive client-focused representation. This involves supporting the development of students' emotional intelligence, and may involve expanding clinical and experiential opportunities in order to help students to further promote their professional, client and negotiation skills. These are crucial lawyering abilities that cannot be displaced by existing artificial intelligence technologies. This may entail a greater focus on helping students to listen with (and for) empathy, examine their own biases (that is, the lenses through which they see and hear people), engage in mindfulness, and better manage the anxieties caused by the disruptions caused by the COVID-19 pandemic, technological change, and social injustice.

99 See Christan Sundquist, Technology and the (Re)Construction of Law, J. LEGAL EDUC. (forthcoming 2021); Drew Simshaw, Ethical Issues in Robo-Lawyering: The Need for Guidance on Developing and Using Artificial Intelligence in the Practice of Law, 70 HASTINGS L.J. 173, 195-207 (2018) (discussing judicial trends in interpreting the impact of technology on "the practice of law"); Lola v. Skadden LLP, 620 F. App'x 37, 45 (2d Cir. 2015) (finding that the plaintiff was not "practicing law" as he only "provided services that a machine could have provided" and "failed to exercise any legal judgment"); Henigv. Quinn Emanuel Urquhart \& Sullivan, LLP, 151 F. Supp. 3d 460, 469-70 (S.D.N.Y. 2015) (holding that the plaintiff was engaged in the "practice of law" as his duties relied on the exercise of legal judgment). 
- Understand and utilize emerging legal technologies.

This may require law schools to create opportunities for law students to work closely with AI programmers to develop and implement future legal technology while being able to critically interrogate the assumptions that underlie legal algorithms. ${ }^{100}$ This may also involve exposing students to the technologies (e.g., document review, automated and "smart" contracts, knowledge management and legal research, and predictive legal analytics) that are being implemented in legal practice.

- Advocate on behalf of clients in virtual and online judicial and administrative tribunals. This may entail restructuring law teaching methodologies to provide students with practical experiences in online lawyering, such as holding virtual oral arguments, meeting with mock clients via Zoom or similar video tele-conferencing tools, conducting mock virtual witness examinations, proffering evidence online, and so forth.

- Envisage "law school" as a center for lifelong learning that can respond to the new and evolving educational needs of both students and alumni. This may require law schools to continue to explore curricular and programmatic offerings beyond the traditional J.D. program, not only to diversify their revenue streams in light of changing enrollment dynamics but also to create opportunities for students to remain nimble and knowledgeable in response to a quickly shifting legal landscape.

- Interact with a diverse range of persons with a deep understanding of systemic bias and inequality. This would involve a renewed focus on developing the cultural competencies of students by intentionally incorporating race and inequality in curriculum, with particular attention paid to offering required courses on antiracism, bias, and cultural competencies during the $1 \mathrm{~L}$ year. The law school of the future should also respond to these social and demographic trends by prioritizing the hiring and retention of diverse tenure-track and tenured BIPOC faculty.

Law schools are facing unprecedented pressure to change from a perfect

${ }^{100}$ See Simshaw, supra note 99, at 208. 
storm of social, public health, and technological forces. The COVID-19 pandemic has only accelerated the ongoing disruptions to legal education and practice caused by technology and social justice activism. Law schools should use this unique moment in time to acknowledge that these structural forces have rendered the traditional education model in need of transformative change, while taking bold measures to thoughtfully envision the law school of the future, today. 